\title{
The role of the intestinal microvasculature in inflammatory bowel disease: studies with a modified Caco-2 model including endothelial cells resembling the intestinal barrier in vitro
}

\author{
This article was published in the following Dove Press journal: \\ International Journal of Nanomedicine \\ 7 December 2016 \\ Number of times this article has been viewed
}

\author{
Jennifer $Y$ Kasper ${ }^{1}$ \\ Maria Iris Hermanns' \\ Christian Cavelius ${ }^{2}$ \\ Annette Kraegeloh ${ }^{2}$ \\ Thomas Jung ${ }^{3}$ \\ Rolf Danzebrink ${ }^{3}$ \\ Ronald E Unger ${ }^{1}$ \\ Charles James Kirkpatrick' \\ 'Institute of Pathology, University \\ Medical Center, Mainz, ${ }^{2}$ Leibniz \\ Institute for New Materials, \\ ${ }^{3}$ NanoGate AG, Goettelborn, \\ Saarbrücken, Germany
}

\begin{abstract}
The microvascular endothelium of the gut barrier plays a crucial role during inflammation in inflammatory bowel disease. We have modified a commonly used intestinal cell model based on the Caco-2 cells by adding microvascular endothelial cells (ISO-HAS-1). Transwell filters were used with intestinal barrier-forming Caco-2 cells on top and the ISO-HAS-1 on the bottom of the filter. The goal was to determine whether this coculture mimics the in vivo situation more closely, and whether the model is suitable to evaluate interactions of, for example, prospective nanosized drug vehicles or contrast agents with this coculture in a physiological and inflamed state as it would occur in inflammatory bowel disease. We monitored the inflammatory responsiveness of the cells (release of IL-8, soluble intercellular adhesion molecule 1, and soluble E-selectin) after exposure to inflammatory stimuli (lipopolysaccharide, TNF- $\alpha$, INF- $\gamma$, IL1- $\beta$ ) and a nanoparticle $\left(\mathrm{Ba} / \mathrm{Gd}\right.$ : coprecipitated $\mathrm{BaSO}_{4}$ and $\left.\mathrm{Gd}(\mathrm{OH})_{3}\right)$, generally used as contrast agents. The barrier integrity of the coculture was evaluated via the determination of transepithelial electrical resistance and the apparent permeability coefficient $\left(\mathrm{P}_{\text {app }}\right)$ of NaFITC. The behavior of the coculture Caco-1/ISO-HAS-1 was compared to the respective monocultures Caco-2 and ISO-HAS-1. Based on transepithelial electrical resistance, the epithelial barrier integrity of the coculture remained stable during incubation with all stimuli, whereas the $\mathrm{P}_{\text {app }}$ decreased after exposure to the cytokine mixture (TNF- $\alpha$, INF- $\gamma$, IL1- $\beta$, and Ba/Gd). Both the endothelial and epithelial monocultures showed a high inflammatory response in both the upper and lower transwell-compartments. However, in the coculture, inflammatory mediators were only detected on the epithelial side and not on the endothelial side. Thus in the coculture, based on the $\mathrm{P}_{\text {app}}$, the epithelial barrier appears to prevent a potential inflammatory overreaction in the underlying endothelial cells. In summary, this coculture model exhibits in vivo-like features, which cannot be observed in conventional monocultures, making the former more suitable to study interactions with external stimuli.
\end{abstract}

Keywords: intestinal microvasculature, inflammatory bowel disease, intestinal barrier in vitro, Caco-2, ISO-HAS-1, soluble E-selectin, sICAM-1, nanosized gadolinium contrast agent

\section{Introduction}

Current research activities underline the relevance of complex, in vitro 3D-cell culture models to establish in vivo-like tissue barriers with a physiological barrier integrity and inflammatory responsiveness upon exposure to external stimuli. These multicellular in vitro models could help gain more insight into inflammatory processes, for example, the intestinal barrier during inflammatory bowel disease (IBD) after treatment with,
Correspondence: Jennifer Y Kasper Dynamische Biomaterialien INM, LeibnizInstitut für Neue Materialien, Campus D2.2 D, 66I23 Saarbrücken, Germany Tel +4968I 930030 I

Email jennifer.kasper@leibniz-inm.de (c) (1) (5) 2016 Kasper et al. This work is published and licensed by Dove Medical Press Limited. The full terms of this license are available at https://www.dovepress.com/terms.php cc) and incorporate the Creative Commons Attribution - Non Commercial (unported, v3.0) License (http://creativecommons.org/licenses/by-nc/3.0/). By accessing the work you hereby accept the Terms. Non-commercial uses of the work are permitted without any further permission from Dove Medical Press Limited, provided the work is properly attributed. For permission for commercial use of this work, please see paragraphs 4.2 and 5 of our Terms (https://www.dovepress.com/terms.php). 
for example, nanoparticulate matter as prospective drug nanovehicles or nanosized contrast agents (CAs) for diagnostic imaging. Thorough analyses are mandatory to assess cytotoxicity and inflammatory potential of these nanomaterials, starting at the biological barrier they would encounter first, that is, the intestinal mucosal barrier. In order to obtain a physiological intestinal in vitro barrier, the model must exhibit a tight diffusion barrier, which is achieved in this study by the well-known human colon adenocarcinoma cell line Caco-2. Another important prerequisite is that the model must exhibit an intestinal inflammatory competence as it is observed in vivo. An impaired mucosal barrier, which comes along with, for example, Crohn's disease (CD) and ulcerative colitis (UC), augments a subepithelial translocation of enteric microbes to the lamina propria. Beside immunocompetent leukocytes, the enteric pathogens will encounter nonimmune cells such as endothelial cells of the intestinal microvasculature. ${ }^{1}$ As a second line of defense, human intestinal microvascular endothelial cells (HIMEC) exhibit, on the one hand, a mechanical barrier against invading microbes. On the other hand, HIMEC play a crucial role in the innate and adaptive immune defense as reviewed by Heidemann et al. ${ }^{1}$ Studies have already demonstrated an upregulation of, for example, IL-8, intercellular adhesion molecule 1 (ICAM-1), and E-selectin in freshly isolated HIMEC under inflammatory conditions. ${ }^{2,3}$

Therefore, a microvascular endothelial cell line model was included in this study to the well-known barrier forming Caco-2 model in order to establish a complex, multicellular intestinal in vitro barrier system to compare with the commonly used monoculture model, which is generally used in research.

For this purpose, the barrier-forming enterocyte cell-line Caco-2 was cultured on the top of a semipermeable transwell filter membrane and the microvascular endothelial cell line ISO-HAS- $1^{4,5}$ on the lower surface. The Caco- 2 cells represent a widely used in vitro model of the intestinal barrier displaying several morphological and biochemical features of small intestinal enterocytes. ${ }^{6-8}$ A similar cell culture system has been used in a number of other epithelial barrier models, such as the lung air-blood barrier and the bronchial barrier model..$^{-13}$ In the present study with the Caco-2/ISO-HAS-1 cell lines, a characterization of the in vitro barrier was performed using immunofluorescence staining and transmission electron microscopy (TEM) to determine if the respective cell-phenotype, cell-cell contacts, and the morphology of the cells were maintained. The barrier properties of the model were determined by measuring the transepithelial electrical resistance (TER) and the transport velocity of NaFITC across the barrier. The inflammatory response behavior of the in vitro barrier was investigated via enzyme-linked immunosorbent assay (ELISA) to determine the release of proinflammatory mediators such as IL-8, soluble ICAM, and soluble E-selectin (sE-selectin) after exposure of the barrier model to several proinflammatory stimuli (lipopolysaccharide [LPS], TNF- $\alpha$, INF- $\gamma$, IL1- $\beta$ ).

Subsequently, a novel, nanoparticulate model compound $(\mathrm{Ba} / \mathrm{Gd})$ was tested on the coculture. $\mathrm{Ba} / \mathrm{Gd}$ consists of coprecipitated $\mathrm{BaSO}_{4}$ and $\mathrm{Gd}(\mathrm{OH})_{3}$ and has a hydrodynamic diameter of 10-35 nm. Many Gd-CA-formulations, which are normally bound in a chelate complex, exhibit toxic systemic side effects by releasing Gd-ions. This may lead to nephrogenic systemic fibrosis in patients suffering from renal insufficiency. ${ }^{14-17}$ Thus, a testing of these compounds for cytotoxicity and their inflammatory potential is indispensable. The effects of $\mathrm{Ba} / \mathrm{Gd}$ were examined in the model representing the "healthy" in vitro barrier, and with the model representing an "inflamed barrier", in which the coculture was first exposed to a proinflammatory cytokine mixture (TNF- $\alpha$, INF- $\gamma$, IL1- $\beta$ ) prior to the addition of $\mathrm{Ba} / \mathrm{Gd}$.

\section{Materials and methods Nanoparticles}

$\mathrm{BaSO}_{4}$-diethylenetriaminpentakis-methylphosphonic acid (DTPMPA)- $\mathrm{Gd}(\mathrm{OH})_{3}(\mathrm{Ba} / \mathrm{Gd})$ was synthesized via coprecipitation of $\mathrm{BaSO}_{4}$ and $\mathrm{Gd}(\mathrm{OH})_{3}$ and kindly provided by Nanogate AG (Quierschied-Göttelborn, Germany). Ba/Gd has a hydrodynamic diameter (dynamic light scattering) of $26.3 \pm 8.2 \mathrm{~nm}$ in ultrapure water, which correlates with TEM analysis (10-35 nm). The zeta-potential of the nanoparticles in ultrapure water was $-44.2 \mathrm{mV}$. The undiluted $\mathrm{Ba} / \mathrm{Gd}$ suspension has a barium concentration of $17,470 \pm 400 \mathrm{mg} / \mathrm{L}$ and a gadolinium concentration of $200.4 \pm 1.5 \mathrm{mg} / \mathrm{L}$. To achieve an appropriate stability of the nanoparticle dispersion, the particle surface was functionalized using DTPMPA. The physicochemical properties, solubility, and ion release were evaluated via inductively coupled plasma optical emission spectrometry. In acidic media, such as artificial stomach acid, a release of gadolinium ions was observed, whereas in pH-neutral media, such as ultrapure water, an ion release was not detected. More detailed information about the synthesis and characterization of the particles has been previously reported (Kraegeloh and NanoKon Konsortium ${ }^{18}$ ).

\section{Cell culture}

Caco-2 (human epithelial colorectal adenocarcinoma cell line) was obtained from $\mathrm{ATCC}^{\circledR}$ (Wesel, Germany) 
(HTB-37 ${ }^{\mathrm{TM}}$ ) and the cells were cultured in DMEM (High Glucose, Gibco, Carlsbad, CA, USA, 41965-039) supplemented with $10 \%$ fetal calf serum, $1 \%$ penicillin/streptomy$\operatorname{cin}(100 \mathrm{U} / 100 \mu \mathrm{g} / \mathrm{mL}), 1 \%$ Glutamax I (Gibco, 35050-038) and $1 \%$ nonessential amino acids (Gibco, 11,140 ) at $37^{\circ} \mathrm{C}$, $5 \% \mathrm{CO}_{2}$. ISO-HAS-1 (human microvascular endothelial cell line ${ }^{4,5}$ ) was grown in RPMI 1640 (Gibco) supplemented with L-glutamine, $10 \%$ fetal calf serum and penicillin/streptomycin $(100 \mathrm{U} / 100 \mu \mathrm{g} / \mathrm{mL})$ and cultivated at $37^{\circ} \mathrm{C}, 5 \% \mathrm{CO}_{2}$. ISO-HAS- 1 and Caco- 2 were passaged every third day at a dilution of $1: 3$ and 1:8, respectively. An ethical approval was not requested nor required for the use of Caco-2 according to ATCC.

\section{Establishing the coculture model of the intestinal barrier Caco-2/ISO-HAS-I}

The coculture was generated as previously described for the lung air-blood barrier H441/ISO-HAS-19-11 with the following alterations. HTS 24-Transwell ${ }^{\circledR}$ filters (polycarbonate, $0.4 \mu \mathrm{m}$ pore size; Costar, Wiesbaden, Germany) were coated with rat tail collagen type-I $\left(12.12 \mu \mathrm{g} / \mathrm{cm}^{2}\right.$; BD Biosciences, Heidelberg, Germany) on both sides. The transwell plate was inverted and the ISO-HAS-1 cells were seeded on the lower side $\left(1 \times 10^{4}\right.$ cells/well). After 2 hours of adhesion at $37^{\circ} \mathrm{C}$ and $5 \% \mathrm{CO}_{2}$, the transwells were inverted and the Caco- 2 cells were seeded in the upper chamber at $6.4 \times 10^{3}$ cells per well. Cells were cultured for 21 days (upper well: $200 \mu \mathrm{L} \mathrm{Caco-2}$ cell culture medium; lower well: $1 \mathrm{~mL}$ ISO-HAS-1 cell culture medium). Cell culture medium was replaced two times per week for the Caco-2 and three times for ISO-HAS-1.

\section{Immunofluorescence staining}

Caco-2 in coculture with ISO-HAS-1 were fixed with paraformaldehyde $3.7 \%$ in PIPES-Buffer (0.1 M Pipes, $1 \mathrm{mM}$ ethylene glycol tetraacetic acid, 4\% polyethyleneglycol 8,000, $0.1 \mathrm{M} \mathrm{NaOH}$ ) for 20 minutes at room temperature (RT). Cells were rinsed $3 \times$ in phosphate-buffered saline (PBS) and permeabilized with $2 \%$ Triton $\times 100$ in PBS for 20 minutes at RT. After washing $3 \times$ with PBS, Caco- 2 were incubated with primary antibodies (diluted in phosphate buffered saline with $1 \%$ bovine serum albumin) against zonula occludens- 1 (ZO-1, 1:200, Zymed 61-7300, Dreieich, Germany) and $\beta$-catenin (1:400, BD, 610154, Heidelberg, Germany) and ISO-HAS-1 against CD31 (1:50, Dako, Hamburg, Germany, M 0823). Cells were washed $3 \times$ with PBS and then the secondary antibodies $(1: 1,000$ in phosphate buffered saline with $1 \%$ bovine serum albumin $1 \%$; Alexa 488, anti-mouse, Invitrogen A11029 and Alexa 546, antirabbit, Invitrogen
A11010, Dreieich, Germany) were added and incubated for 1 hour at RT. After three washing steps with PBS, cells were stained with Hoechst 33,342 (1:10,000 in PBS) for 5 minutes at RT and washed three times. Finally, transwell filters were removed by cutting around the edge of the well and were mounted with Fluoromount-GTM (Southern Biotech, Birmingham, UK). Images were obtained using a fluorescence microscope (DeltaVision, Applied Precision, Freiburg, Germany).

\section{Transmission electron microscopy}

For TEM, transwell filters with cells were prepared as previously described. ${ }^{11}$ Briefly, cells were fixed in $2.5 \%$ glutaraldehyde in cacodylate buffer $(\mathrm{pH}$ 7.2) for 30 minutes then fixed in $1 \% \mathrm{OsO}_{4}$ for 2 hours and dehydrated in graded ethanol. The coverslips with cells were carried through propylene oxide as an intermedium; then, the samples were embedded in agar 100 resin (PLANO, Wetzlar, Germany) and submitted to polymerization at $60^{\circ} \mathrm{C}$ for 48 hours. Ultrathin sections were cut with an ultramicrotome (Leica, Bensheim, Germany). The sections were then placed onto copper grids, and ultrastructural analysis was performed with a transmission electron microscope (model EM 410; Philips, Eindhoven, the Netherlands).

\section{Stimulation of the coculture with inflammatory mediators}

The coculture was apically treated with LPS $(1 \mu \mathrm{g} / \mathrm{mL})$, IL1- $\beta(100 \mathrm{U} / \mathrm{mL})$, TNF- $\alpha(600 \mathrm{U} / \mathrm{mL})$ or IFN- $\gamma(200 \mathrm{U} / \mathrm{mL})$, respectively, and in combination (3C: IL $1-\beta$, TNF- $\alpha$, and IFN- $\gamma$, same concentrations as mentioned for the individual LPS or cytokine treatment) for 24 hours. The $\mathrm{Ba} / \mathrm{Gd}$ particle suspension was applied apically at a concentration of $500 \mu \mathrm{g} / \mathrm{mL}$. All stimulants were applied to the cells on the transwells in a final working volume of $200 \mu \mathrm{L} /$ well $(20 \mu \mathrm{L}$ stimulant solution $+180 \mu \mathrm{L}$ cell culture medium).

\section{Transepithelial electrical resistance}

The barrier integrity was determined via TER. TER was measured before and after 24 hours incubation with the stimulants using an EVOM voltohmmeter (World Precision Instruments, Berlin, Germany) equipped with an STX-2 chopstick electrode. An empty well (without cells) was utilized as blank $(\sim 110 \Omega)$. Barrier resistance readings $(\Omega)$ were obtained for each well individually and after subtracting the blank they were then multiplied by the membrane area $\left(0.33 \mathrm{~cm}^{2}\right)$ to give $\Omega * \mathrm{~cm}^{2}$. The TER value of each single well before the 
stimulation $\mathrm{t}_{0}$ was set as $100 \%$ to normalize the value of the same well after 24 hours.

\section{Inflammatory responses}

The supernatants were examined for IL-8, soluble intercellular adhesion molecule-1 (sICAM-1) and sE-selectin released by the cells via ELISA (DuoSet R\&D, DY208, DY720, DY724, Minneapolis, MN, USA) according to the manufacturer's recommendations.

\section{Transport assay}

After 24 hours incubation with the various stimulants, $10 \mu \mathrm{g} / \mathrm{mL}$ NaFITC was applied to the upper compartment of the transwell. After 3 hours, $50 \mu \mathrm{L}$ cell culture medium of the lower compartments was removed to a 96-well plate with $200 \mu \mathrm{L} 0.4 \mathrm{mM} \mathrm{NaOH}$. Fluorescence (EX 488) was checked by means of a fluorescence plate reader. The apparent permeability coefficient $\left(\mathrm{P}_{\text {app }}\right)$ was determined via the equation: $\mathrm{P}_{\text {app }}[\mathrm{cm} / \mathrm{s}]=\left(1 /\left(\mathrm{A}^{*} \mathrm{C}_{0}\right)\right) *(\mathrm{dQ} / \mathrm{dt})$ with $\mathrm{A}=$ filter
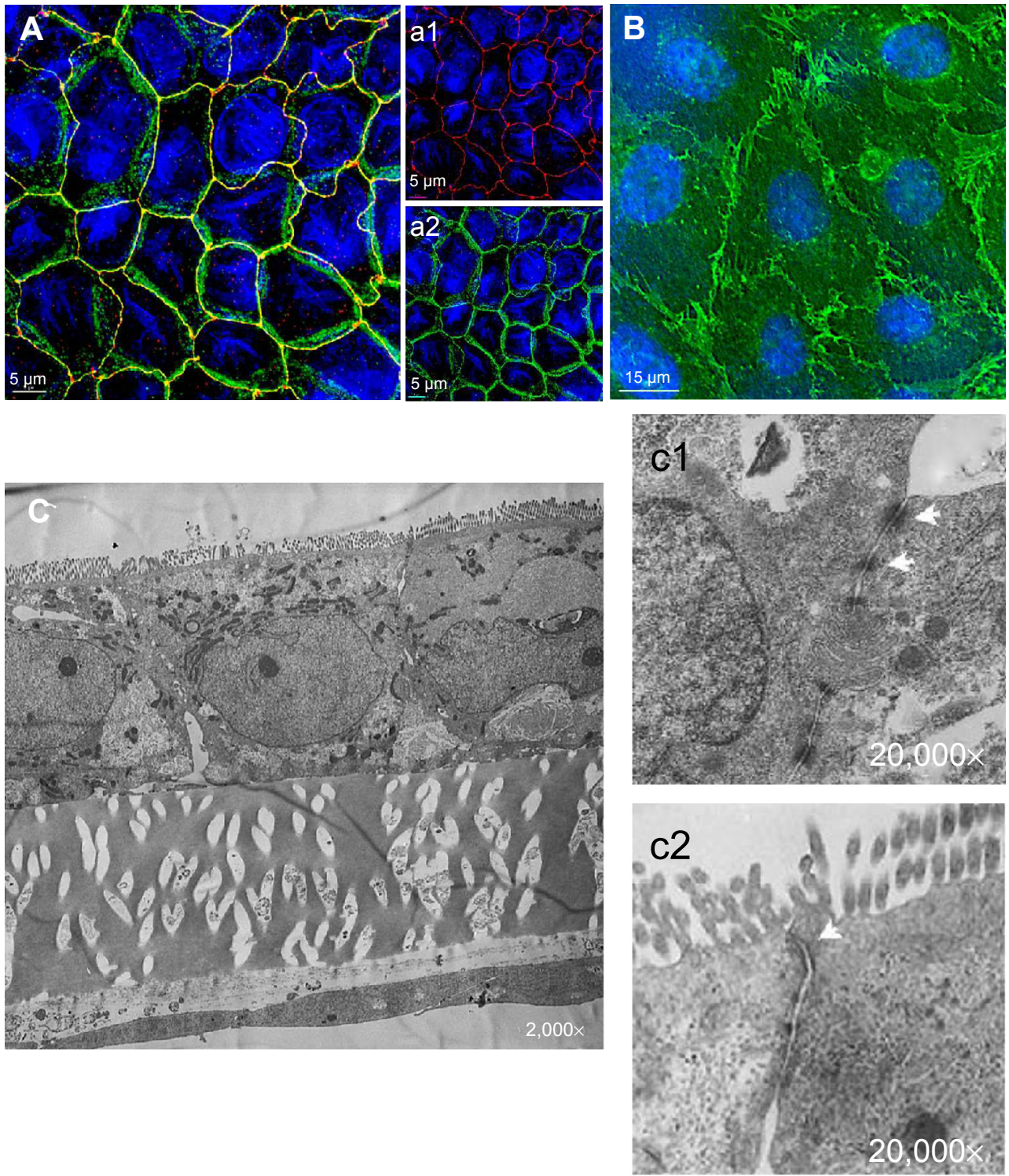

Figure I Immunofluorescence and TEM of the Caco/2/ISO-HAS-I coculture.

Notes: ([A], al and a2) Immunofluorescence staining of tight junctional proteins (ZO-I, red signal [A], a I) and adherens junctional proteins (beta-catenin, green signal [A], a2) of Caco-2 after 21 days in coculture with ISO-HAS-I on the opposite side of the filter membrane. ZO-I and beta-catenin appeared well developed. TEM images corroborate these observations, desmosomal ([C] cl, arrows) as well as tight junctional ([C] c2, arrows) complexes appear well defined. (B) CD3I staining of the ISOHAS-I cells underneath the Caco-2 layer. A well-developed endothelial monolayer could be detected. Nuclei (blue signal, Hoechst 33342 ) scale bar for fluorescence images (A), al and a2: $5 \mu \mathrm{m}$; (B) I5 $\mu \mathrm{m}$. (C) TEM cross-section through a transwell filter membrane with Caco-2 on the top side and ISO-HAS-I on the bottom side (magnifications C: 2,000x; cl, c2: 20,000x).

Abbreviations: TEM, transmission electron microscopy; ZO-I, zona occludens-I. 
surface $\left(0.33 \mathrm{~cm}^{2}\right), \mathrm{C}_{0}=$ Concentration of NaFITC in the donor solution $(10 \mu \mathrm{g} / \mathrm{mL}), \mathrm{dQ} / \mathrm{dt}$ (paracellular flux $)=$ amount of $\operatorname{NaFITC}(\mu \mathrm{g} / \mathrm{s})$, which is transported across the cellular layer within 3 hours. An empty transwell filter membrane (without cells) was used as blank (mentioned as filter in the graph).

\section{Statistical analysis}

From several independent measurements, means and standard deviations (SD) were calculated. Data are shown as mean \pm SD from at least three separate experiments. Testing for significant differences between means was carried out using one-way analysis of variance and Dunnett's Multiple Comparison test at a probability of error of $5 \%(*), 1 \%(* *)$, and $0.1 \%(* * *)$.

\section{Results}

Figure 1A (a1 and a2) illustrates the immunofluorescence staining patterns of tight junctional proteins (ZO-1, red signal) and adherens junctional proteins ( $\beta$-catenin, green signal) of the Caco- 2 cells after 21 days in coculture with ISO-HAS- 1 on the opposite side of the filter membrane. ZO-1 and $\beta$-catenin appeared well developed and showed typical staining patterns for Caco-2. Figure 1B depicts CD31 (Pecam-1) staining of the ISO-HAS-1 cells on the opposite side of the filter containing the Caco-2 layer. TEM images corroborate these observations, with desmosomal (Figure 1, C[c1]) as well as tight junctional (Figure 1C[c2]) complexes appearing well defined. Moreover, the ultrastructural study confirmed the formation of a well polarized monolayer of epithelial cells in coculture with the endothelial cells (Figure 1C). A well-developed endothelial monolayer was observed. A morphological comparison concerning cell contacts of Caco-2 in mono- (data not shown) and coculture with ISO-HAS-1 (Figure 1) did not reveal any obvious differences by visual judgment of fluorescence or TEM images. For this reason the focus was placed on transepithelial resistance measurements and the transport of NaFITC. The TER and transport assay of NaFITC across the coculture barrier are shown in Figure 2. After 21 days, Caco-2 in coculture with ISO-HAS-1 showed a TER of $250 \pm 59 \Omega * \mathrm{~cm}^{2}$, whereas the Caco-2 monoculture developed a significant higher TER $\left(355 \pm 58 \Omega * \mathrm{~cm}^{2}\right)$. However, the TER of the coculture was still sufficient to determine the influence of compounds on the barrier integrity. The transport-assay using NaFITC revealed comparable results to the TER with Caco-2 monoculture $\left(\mathrm{P}_{\text {app }}: 9.6 \times 10^{-6} \mathrm{~cm} / \mathrm{s}\right)$ as well as coculture with ISO-HAS-1 $\left(\mathrm{P}_{\text {app }}: 1.1 \times 10^{-5} \mathrm{~cm} / \mathrm{s}\right)$.

Figure 3 illustrates the inflammatory responses (release of IL8) of the monocultures of Caco-2 (Figure 3A) and ISO-HAS-1 (Figure 3B) and the coculture Caco-2/ISO-HAS-1 (Figure 3C) after apical treatment with several inflammatory stimuli (LPS: $1 \mu \mathrm{g} / \mathrm{mL}, \mathrm{TNF}-\alpha$ : $600 \mathrm{U} / \mathrm{mL}, \mathrm{INF}-\gamma: 200 \mathrm{U} / \mathrm{mL}$, IL1- $\beta$ : $100 \mathrm{U} / \mathrm{mL}$ and 3C (cytokine cocktail: TNF- $\alpha$, INF- $\gamma$, IL1- $\beta)$ as well as the nanoparticle $\mathrm{Ba} / \mathrm{Gd}(500 \mu \mathrm{g} / \mathrm{mL})$. For the Caco-2 monoculture, no significant IL-8 release could be observed in response to the different individual stimuli when compared to control. After treatment with IL1- $\beta$, however, a significant decrease was detected for the lower compartment of the Caco-2 monoculture $(28.6 \pm 3.5 \mathrm{pg} / \mathrm{mL}$ compared to the untreated control [uc]: $54 \pm 1 \mathrm{pg} / \mathrm{mL}$ ). However, the basolateral IL-8 amount of the uc was very
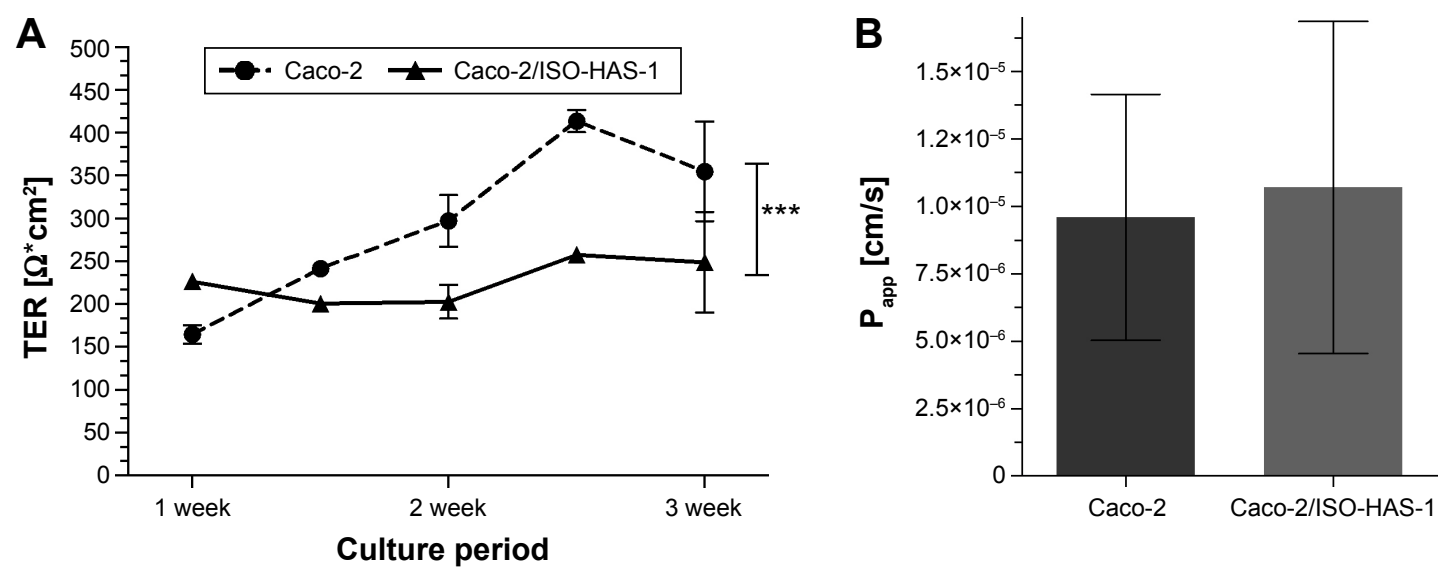

Figure 2 TER of Caco-2 in monoculture (dashed line) and coculture with ISO-HAS-I (continuous line) after 21 days in culture.

Notes: (A) The Caco-2 monoculture developed a significant higher TER compared to the Caco-2 in coculture, but it is still high enough and sufficient to influence external impact on barrier integrity. $(B)$ The transport-assay $\left(\mathrm{P}_{\text {app }}\right)$ using NaFITC revealed comparable results in the Caco-2 monoculture as well as coculture with ISO-HAS-I. Data are shown as mean \pm SD from at least three separate experiments. Testing for significant differences between means was carried out using one-way ANOVA and Dunnett's Multiple Comparison test at a probability of error of $0.1 \%$ (***).

Abbreviations: ANOVA, analysis of variance; LPS, lipopolysaccharide; SD, standard deviation; TER, transepithelial electrical resistance; uc, untreated control. 

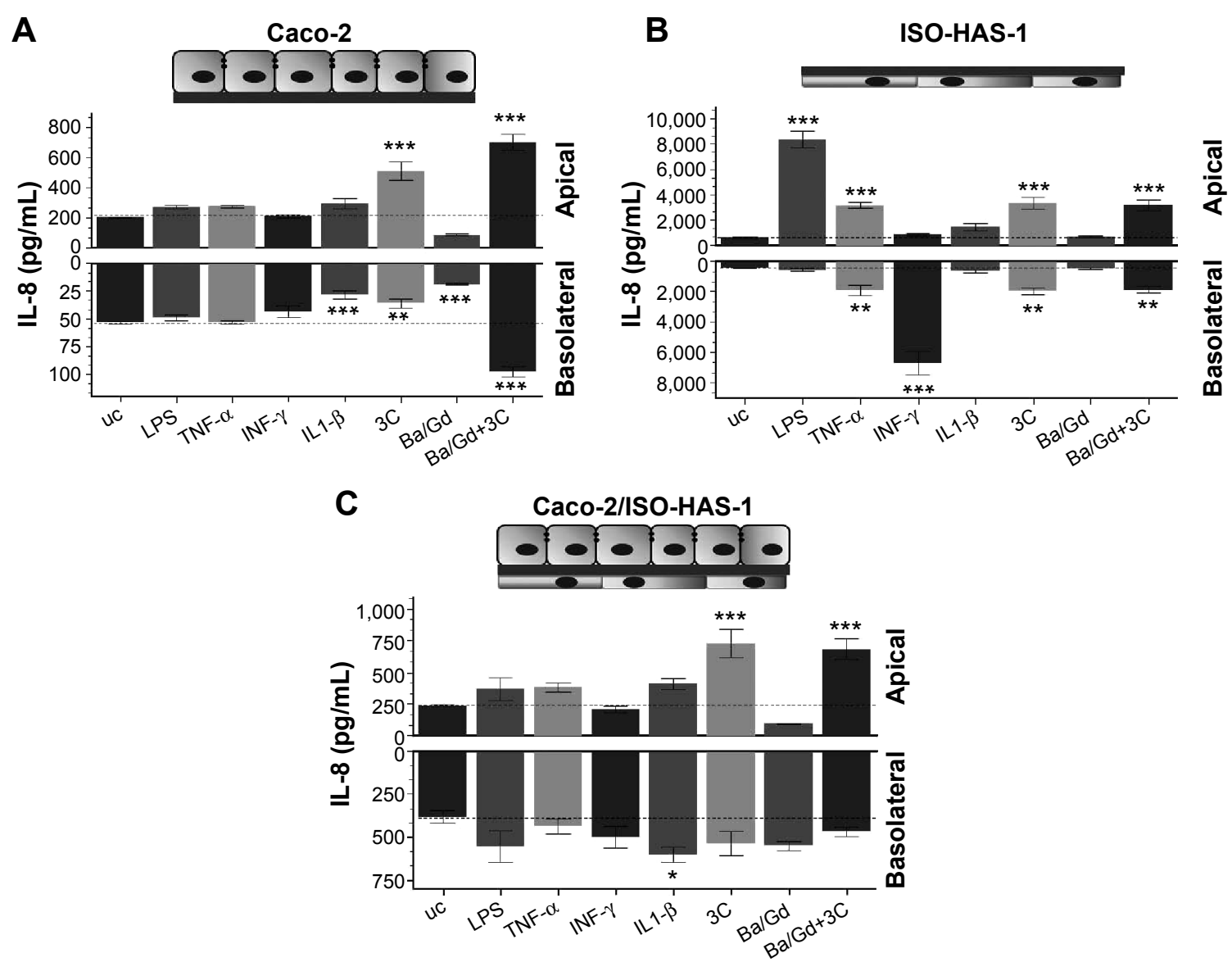

Figure 3 IL-8 release of the monocultures of Caco-2 ([A], seeded on the upper side of the transwell) and ISO-HAS-I ([B], seeded on the lower side of the transwell) as well as the coculture Caco-2/ISO-HAS-I (C).

Notes: All test substances were applied to the apical side (upper well) in mono- as well as cocultures. Cultures were treated with several inflammatory stimuli (LPS, I $\mu \mathrm{g} / \mathrm{mL}$; TNF- $\alpha, 600 \mathrm{U} / \mathrm{mL}$; INF- $\gamma, 200 \mathrm{U} / \mathrm{mL}$; ILI- $\beta, 100 \mathrm{U} / \mathrm{mL}$; and 3C [cytokine cocktail, TNF- $\alpha$, INF- $\gamma$, ILI- $\beta$ ]) as well as the nanoparticle Ba/Gd (500 $\mu$ g/mL). Upper columns depict IL-8 release into the upper compartments (apical) and the lower columns illustrate the IL-8 release into the lower compartment (basolateral, depicted as negative value). Data are shown as mean \pm SD from at least three separate experiments. Testing for significant differences between means was carried out using one-way ANOVA and Dunnett's Multiple Comparison test at a probability of error of $5 \%(*), I \%(* *)$, and $0.1 \%(* * *)$.

Abbreviations: ANOVA, analysis of variance; LPS, lipopolysaccharide; SD, standard deviation; uc, untreated control; 3C, cytokine cocktail, TNF- $\alpha$, INF- $\gamma$, ILI- $\beta$.

low and a further decrease after IL1- $\beta$ treatment can be considered as negligible. The cytokine mixture (3C) resulted in a comparable IL-8 decrease $(36 \pm 4.7 \mathrm{pg} / \mathrm{mL})$, whereas in the upper well IL-8 increased significantly $(513 \pm 62 \mathrm{pg} / \mathrm{mL}$, compared to the uc: $204.5 \pm 3.5 \mathrm{pg} / \mathrm{mL})$. Ba/Gd alone caused a significant IL-8 decrease in both (apical: $85.5 \pm 6.6 \mathrm{pg} / \mathrm{mL}$; basolateral: $19 \pm 0.6 \mathrm{pg} / \mathrm{mL}$ ) compartments. Interestingly, compared to all other stimulants, $\mathrm{Ba} / \mathrm{Gd}$ in combination with $3 \mathrm{C}$ caused the highest increase of IL-8 in both compartments (apical: $702.8 \pm 53 \mathrm{pg} / \mathrm{mL}$ and basolateral: $97.7 \pm 4.7 \mathrm{pg} / \mathrm{mL}$ ). The ISO-HAS-1 monoculture (cells were seeded on the lower surface, stimulants were applied on the upper surface) showed a significant IL-8 increase $(8,398 \pm 672 \mathrm{pg} / \mathrm{mL}$, compared to the uc: $610 \pm 77 \mathrm{pg} / \mathrm{mL}$ ) after LPS treatment in the apical compartment, while after TNF- $\alpha$ treatment, increased IL-8 levels were observed in both compartments (apical: $3,143 \pm 212 \mathrm{pg} / \mathrm{mL}$, basolateral: $1,948 \pm 328 \mathrm{pg} / \mathrm{mL}$; compared to the uc, apical: $610 \pm 77 \mathrm{pg} / \mathrm{mL}$ and basolateral: $431.3 \pm 35 \mathrm{pg} / \mathrm{mL}$ ).

A significant IL-8 release in the lower compartment was observed after IFN- $\gamma$ treatment, however, IL1- $\beta$ as well as the nanoparticle $\mathrm{Ba} / \mathrm{Gd}$ did not affect IL-8 release in either of the compartments. The treatment with $3 \mathrm{C}$ showed a slight but significantly elevated IL-8 release in both compartments (apical: 3,333 $\pm 460 \mathrm{pg} / \mathrm{mL}$, basolateral: 2,000 $\pm 218 \mathrm{pg} / \mathrm{mL}$, compared to the uc, apical: $610 \pm 77 \mathrm{pg} / \mathrm{mL}$ and basolateral: $431.3 \pm 35 \mathrm{pg} / \mathrm{mL}$ ). The simultaneous application of $\mathrm{Ba} / \mathrm{Gd}$ with $3 \mathrm{C}$ did not cause any significant alteration compared to the response observed after $3 \mathrm{C}$ exposure alone (apical: $3,161 \pm 441 \mathrm{pg} / \mathrm{mL}$ and basolateral: $1,882 \pm 226 \mathrm{pg} / \mathrm{mL}$ ). The coculture Caco-2/ISO-HAS-1 exhibited a similar pattern of expression compared to the Caco-2 
monoculture. LPS, TNF- $\alpha$, IFN- $\gamma$ did not cause any elevated IL-8 levels, in the apical or basolateral compartments. After $3 \mathrm{C}$ and $\mathrm{Ba} / \mathrm{Gd}+3 \mathrm{C}$ treatment a comparable IL- 8 increase was observed in the upper well of the coculture $(682 \pm 80 \mathrm{pg} / \mathrm{mL})$ compared to the Caco- 2 monoculture. On the contrary to the Caco-2 and ISO-HAS-1 monocultures, no significant alteration of the IL-8 release was observed after $3 \mathrm{C}+\mathrm{Ba} / \mathrm{Gd}$ in the lower compartment of the coculture. Stimulation with the cytokine mixture $3 \mathrm{C}$ caused an elevated IL-8 release $(727 \pm 111 \mathrm{pg} / \mathrm{mL})$ apically, which was not significantly altered by the addition of $\mathrm{Ba} / \mathrm{Gd}$ to the $3 \mathrm{C}$ mixture.

The release of the SICAM-1 was also determined for all three culture conditions with and without the various stimulants (Figure 4A [Caco-2 monoculture], B [ISO-HAS-1 monoculture], and $\mathrm{C}$ [Caco-2/ISO-HAS-1 coculture]). In the Caco-2 monoculture, a significantly increased
sICAM-1 level was detectable after stimulation with IFN- $\gamma$ $(5,695 \pm 1,693 \mathrm{pg} / \mathrm{mL}$, compared to uc $2,034 \pm 77 \mathrm{pg} / \mathrm{mL})$ but not after LPS or TNF- $\alpha$ treatment. An even higher apical increase was observed for IL1- $\beta(10,961 \pm 935 \mathrm{pg} / \mathrm{mL})$. All four stimulants alone did not cause any sICAM-1 response in the basolateral compartment. Surprisingly, the cytokine mixture $3 \mathrm{C}$ resulted in a very large reduction in SICAM-1 in both compartments (apical: $568 \pm 77 \mathrm{pg} / \mathrm{mL}$ and basolateral: $36 \pm 4 \mathrm{pg} / \mathrm{mL}$, compared to the uc, apical: $2,034 \pm 77 \mathrm{pg} / \mathrm{mL}$ and basolateral: $123 \pm 4.5 \mathrm{pg} / \mathrm{mL}$ ). Apical incubation with the nanoparticle $\mathrm{Ba} / \mathrm{Gd}$ caused a significant sICAM-1 elevation in both compartments (apical: 5,527 $\pm 241 \mathrm{pg} / \mathrm{mL}$ and basolateral: $354 \pm 45 \mathrm{pg} / \mathrm{mL}$ ) and the simultaneous incubation of $3 \mathrm{C}$ with $\mathrm{Ba} / \mathrm{Gd}$ resulted in a further large increase in sICAM-1 production in both compartments (apical: 16,411 $\pm 1,570 \mathrm{pg} / \mathrm{mL}$ and basolateral: $627 \pm 55 \mathrm{pg} / \mathrm{mL}$ ).

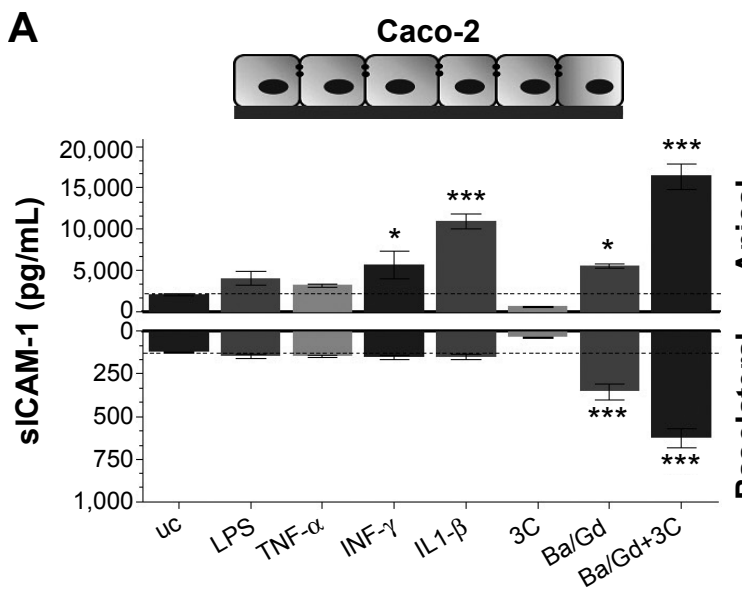

B

SO-HAS-1

C

Caco-2/ISO-HAS-1
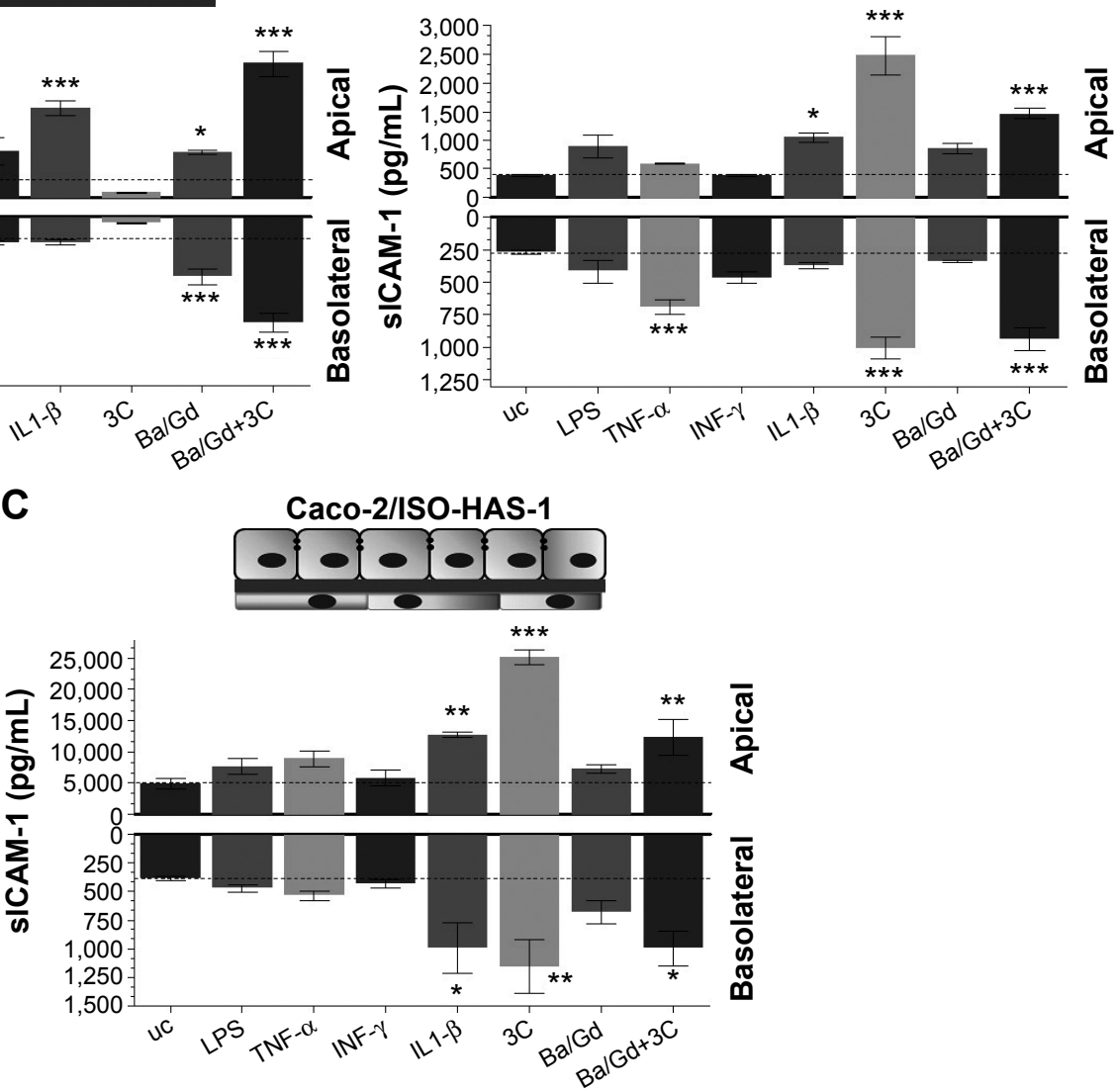

Figure 4 sICAM-I release of the monocultures of Caco-2 ([A], seeded on the upper side of the transwell) and ISO-HAS-I ([B], seeded on the lower side of the transwell) as well as the coculture Caco-2/ISO-HAS-I (C).

Notes: All test substances were applied to the apical side (upper well) in mono- as well as cocultures. The various cell culture models were treated with several inflammatory stimuli (LPS, I $\mu \mathrm{g} / \mathrm{mL}$; TNF- $\alpha, 600 \mathrm{U} / \mathrm{mL}$; INF- $\gamma, 200 \mathrm{U} / \mathrm{mL}$; ILI- $\beta, 100 \mathrm{U} / \mathrm{mL}$; and 3C [cytokine cocktail: TNF- $\alpha$, INF- $\gamma$, ILI- $\beta$ ]) as well as the nanoparticle Ba/Gd (500 $\mu \mathrm{g} / \mathrm{mL})$. Upper columns depict sICAM-I release into the upper compartments (apical) and the lower columns show sICAM-I release into the lower compartment (basolateral, depicted as negative value). Data are shown as mean \pm SD from at least three separate experiments. Testing for significant differences between means was carried out using one-way ANOVA and Dunnett's Multiple Comparison test at a probability of error of $5 \%(*), 1 \%(* *)$, and $0.1 \%(* * *)$.

Abbreviations: ANOVA, analysis of variance; LPS, lipopolysaccharide; SD, standard deviation; sICAM-I, soluble intercellular adhesion molecule I; uc, untreated control. 
For the ISO-HAS-1 monoculture, treatment with LPS elicited a minor but not significant SICAM-1 increase in both compartments (apical: $898 \pm 197 \mathrm{pg} / \mathrm{mL}$ and basolateral: $415 \pm 89 \mathrm{pg} / \mathrm{mL}$, compared to the uc, apical: $379 \pm 14 \mathrm{pg} / \mathrm{mL}$ and basolateral: $268 \pm 15 \mathrm{pg} / \mathrm{mL}$ ). After exposure to TNF- $\alpha$ higher sICAM-1 values were only detected in the basolateral compartment $(687 \pm 58 \mathrm{pg} / \mathrm{mL})$, whereas after IL1- $\beta$-treatment, an sICAM-1 increase was measured in the apical compartment $(1,048 \pm 86 \mathrm{pg} / \mathrm{mL})$. The cytokine mixture $3 \mathrm{C}$ caused a very large elevation of sICAM- 1 in both compartments (apical: $2,480 \pm 336 \mathrm{pg} / \mathrm{mL}$ and basolateral: $1,004 \pm 85 \mathrm{pg} / \mathrm{mL}$ ). The addition of $\mathrm{Ba} / \mathrm{Gd}$ did not significantly alter the sICAM-1 response to $3 \mathrm{C}$, whereas $\mathrm{Ba} / \mathrm{Gd}$ alone caused a minor but not significant sICAM-1 increase in the upper well $(855 \pm 90 \mathrm{pg} / \mathrm{mL})$. The coculture responded differently compared to the Caco-2 and ISOHAS- 1 monoculture. LPS, TNF- $\alpha$, and IFN- $\gamma$ did not cause any significant elevation of sICAM-1 release. IL1- $\beta$, however, caused a significant sICAM-1 response in both wells (apical: 12,679 \pm 434 and basolateral: $995 \pm 221 \mathrm{pg} / \mathrm{mL}$, compared to the uc apical: $4,885 \pm 908 \mathrm{pg} / \mathrm{mL}$ and basolateral: $387 \pm 22 \mathrm{pg} / \mathrm{mL}$ ). The $3 \mathrm{C}$ cytokine mixture resulted in an even higher sICAM-1 release compared to IL1- $\beta$ (apical: $25,159 \pm 1,117$ and basolateral: $1,159 \pm 233 \mathrm{pg} / \mathrm{mL}$ ). No obvious sICAM-1 response was observed after the treatment with $\mathrm{Ba} / \mathrm{Gd}$ alone. The combination of $\mathrm{Ba} / \mathrm{Gd}$ and $3 \mathrm{C}$ triggered an SICAM-1 increase in both the upper and lower well, but was less than $3 \mathrm{C}$ alone (apical: $12,338 \pm 2,922$ and basolateral: $995 \pm 150 \mathrm{pg} / \mathrm{mL}$ ). Figure 5 (A: Caco-2 monoculture; B: ISO-HAS-1 monoculture; C: Caco-2/ ISO-HAS-1 coculture) depicts the release of the soluble form of E-selectin. The Caco-2 monoculture (Figure 5A) acted as a cellular control, as E-selectin is not synthesized by epithelial cells. The values represent background in the
A

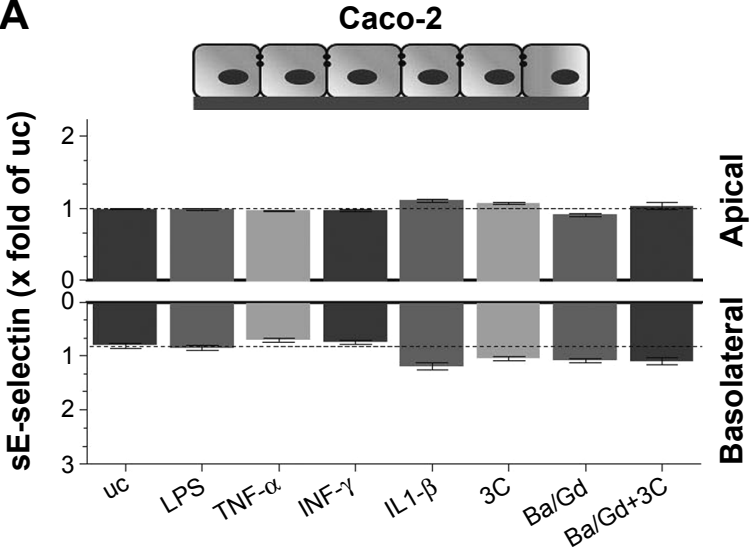

B

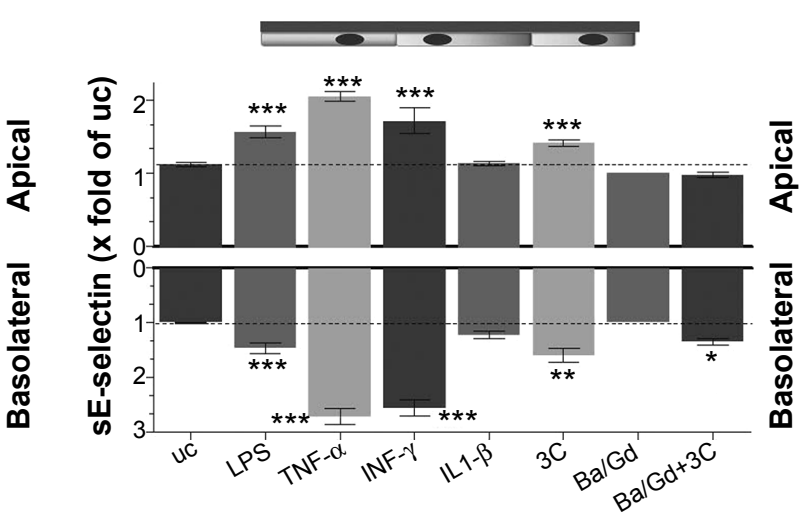

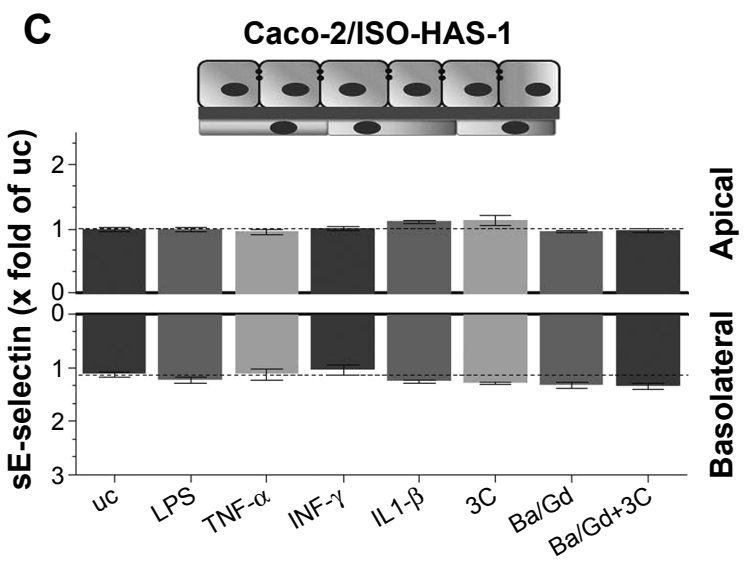

Figure 5 Soluble E-selectin (sE-selectin) release of the monocultures of Caco-2 ([A], seeded on the upper side of the transwell) and ISO-HAS-I ([B], seeded on the lower side of the transwell) as well as the coculture Caco-2/ISO-HAS-I (C).

Notes: All test substances were applied to the apical side (upper well) in mono- as well as cocultures. The various cell culture models were treated with several inflammatory stimuli (LPS, I $\mu \mathrm{g} / \mathrm{mL} ; \mathrm{TNF}-\alpha, 600 \mathrm{U} / \mathrm{mL}$; INF- $\gamma, 200 \mathrm{U} / \mathrm{mL}$; ILI- $\beta, 100 \mathrm{U} / \mathrm{mL}$, and 3C (cytokine cocktail: TNF- $\alpha$, INF- $\gamma$, ILI- $\beta$ )) as well as the nanoparticle Ba/Gd (500 $\mu \mathrm{g} / \mathrm{mL}$ ). Upper columns depict sE-selectin release into the upper compartments (apical) and the lower columns illustrate sE-selectin release into the lower compartment (basolateral, depicted as negative value). Data are shown as mean \pm SD from at least three separate experiments. Testing for significant differences between means was carried out using one-way ANOVA and Dunnett's Multiple Comparison test at a probability of error of $5 \%(*), 1 \%(* *)$, and $0.1 \%(* * *)$.

Abbreviations: ANOVA, analysis of variance; LPS, lipopolysaccharide; SD, standard deviation; sE-selectin, soluble E-selectin; uc, untreated control. 

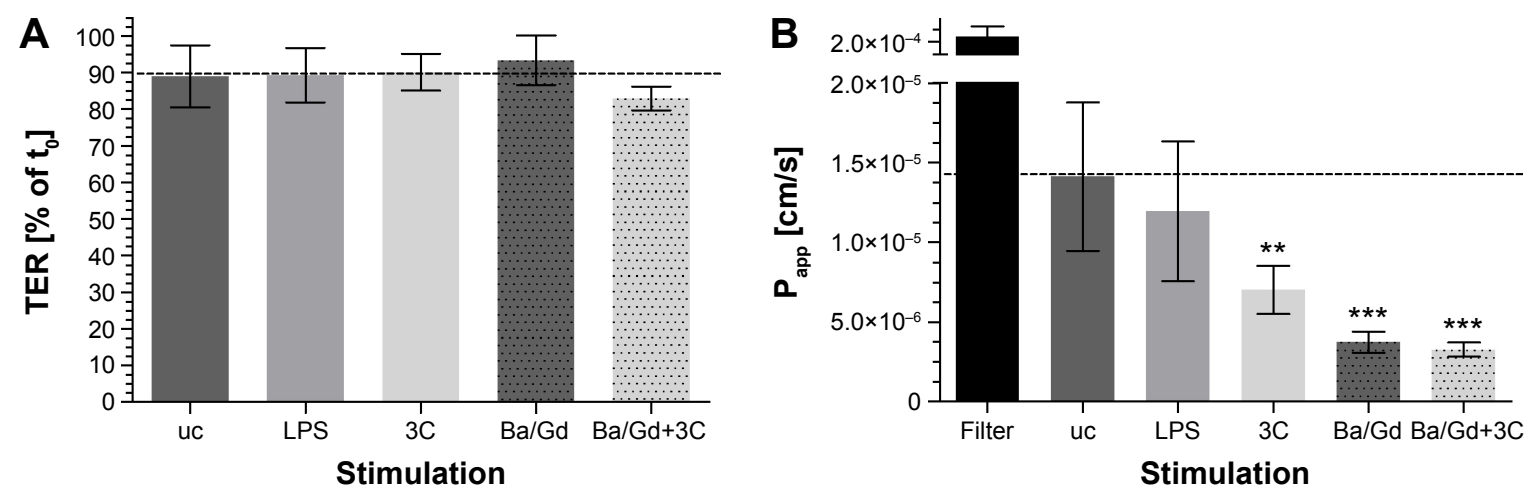

Figure 6 TER and transport-assay $\left(\mathrm{P}_{\text {app }}\right.$ ) using NaFITC of the coculture Caco-2/ISO-HAS-I after apical (upper well) treatment with LPS: I $\mu$ g/mL and 3C (cytokine-cocktail: TNF- $\alpha$ : $600 \mathrm{U} / \mathrm{mL}$, INF- $\gamma: 200 \mathrm{U} / \mathrm{mL}$, ILI $-\beta$ : $100 \mathrm{U} / \mathrm{mL})$ as well as the nanoparticle Ba/Gd $(500 \mu \mathrm{g} / \mathrm{mL})$ with and without 3C.

Notes: The horizontal dotted line illustrates TER $(\mathbf{A})$ and $\mathrm{P}_{\text {app }}(\mathbf{B})$ of the uc. Moreover, measured values are given as a percentage of the TER value $t_{0}$, which is $250 \pm 59$ $\Omega^{*} \mathrm{~cm}^{2}$. The $P_{\text {app }}$ of an empty transwell filter without cells (filter) was added to the graph as a point of reference. Data are shown as mean \pm SD from at least three separate experiments. Testing for significant differences between means was carried out using one-way ANOVA and Dunnett's Multiple Comparison test at a probability of error of $1 \%(* *)$, and $0.1 \%(* * *)$.

Abbreviations: ANOVA, analysis of variance; LPS, lipopolysaccharide; SD, standard deviation; TER, transepithelial electrical resistance; uc, untreated control; $\mathrm{P}_{\text {app }}$, apparent permeability coefficient.

assay and show no intergroup differences across the entire spectrum of stimuli used. By contrast, significant changes in sE-selectin in both compartments were observed in the ISOHAS-1 monoculture upon exposure to LPS (apical: 1.6 \pm 0.1 fold of the uc and basolateral: $1.5 \pm 0.1$ fold of uc), TNF- $\alpha$ (apical: $2.1 \pm 0.07$ fold of uc and basolateral: $2.7 \pm 0.1$ fold of uc) and IFN- $\gamma$ (apical: $1.7 \pm 0.2$ fold of uc and basolateral: $2.6 \pm 0.2$ fold of $u c)$.

IL1- $\beta$ and the particle $\mathrm{Ba} / \mathrm{Gd}$ did not cause any alteration compared to the uc. The cytokine mixture $3 \mathrm{C}$ caused a minor but still significant $\mathrm{sE}$-selectin release in the upper $(1.4 \pm 0.05$ fold of uc) as well as in the lower well (1.6 \pm 0.1 fold of uc), whereas after treatment with the combination of $\mathrm{Ba} / \mathrm{Gd}$ and $3 \mathrm{C}$, only a minor but nevertheless significant E-selectin release was observed in the lower compartment (1.3 \pm 0.05 fold of uc).

The coculture Caco-2/ISO-HAS-1 displayed a similar result as the Caco-2 monoculture. Increased E-selectin levels were not observed on the endothelial side (basolateral).

Figure 6 shows the barrier properties of the coculture Caco-2/ISO-HAS-1 after treatment with selected stimulants such as LPS, $3 \mathrm{C}, \mathrm{Ba} / \mathrm{Gd}$, and $3 \mathrm{C}+\mathrm{Ba} / \mathrm{Gd}$. The TER remained stable over the entire incubation period with the tested inflammatory stimuli. The apparent permeability coefficient $\mathrm{P}_{\text {app }}$, however, decreased significantly after stimulation with the cytokine mixture $3 \mathrm{C}\left(\mathrm{P}_{\text {app }}: 7 \times 10^{-6} \mathrm{~cm} / \mathrm{s}\right.$, compared to the uc $\left.\mathrm{P}_{\text {app }}: 1.4 \times 10^{-5} \mathrm{~cm} / \mathrm{s}\right)$ and further decreased after stimulation with $\mathrm{Ba} / \mathrm{Gd}\left(3.7 \times 10^{-6} \mathrm{~cm} / \mathrm{s}\right)$ and $3 \mathrm{C}+\mathrm{Ba} / \mathrm{Gd}$ $\left(3.2 \times 10^{-6} \mathrm{~cm} / \mathrm{s}\right)$. The $\mathrm{P}_{\text {app }}$ of an empty transwell filter without cells (filter: $2.2 \times 10^{-4} \mathrm{~cm} / \mathrm{s}$ ) was added to the graph as a point of reference.

\section{Discussion}

A number of intestinal in vitro models have now been developed using relevant tissue-specific cell types such as fibroblasts ${ }^{19,20}$ or immune cells such as macrophages and dendritic cells ${ }^{21,22}$ added to the barrier forming enterocytes such as Caco-2. As previously reviewed, the microvascular endothelium of the intestinal villi also plays a crucial role in the innate and adaptive immune defense and accordingly also in the pathogenesis of IBDs. ${ }^{1}$ Therefore, we developed a cellular model system - in which the barrier-forming enterocyte cell-line Caco-2 was cocultured with the microvascular endothelial cell line ISO-HAS- $1^{4,5}$ and on the opposite side of a transwell filter membrane. This model was used to examine intestinal inflammatory responses after exposure to diverse inflammatory stimuli and a nanoparticle $\mathrm{Ba} / \mathrm{Gd}$, which was intended as a prospective CA for medical diagnostic imaging of IBD via X-ray or magnetic resonance imaging. In order to stimulate an inflammatory response, the in vitro barrier model was exposed to TNF- $\alpha$, INF- $\gamma$, and IL1- $\beta$, which are involved in a significant manner in IBD. ${ }^{23}$ The Caco-2 monoculture did not respond with an increased IL-8 level upon stimulation with the single proinflammatory mediators. Using a mixture of all three cytokines (3C), an apical release of IL-8 was detected, whereas in the basolateral compartment, a decrease of IL-8 was observed compared to the uc. As previously reviewed by Peterson and Artis, ${ }^{24}$ intestinal epithelial cells play an important role in homeostasis of the mucosal immune cells and are involved in orchestrating an appropriate immune response toward external stimuli. By strengthening their barrier function after exposure to external stimuli, they prevent a subepithelial translocation of the 
stimulating substances. This minimizes the risk of developing an acute or chronic inflammatory response as it occurs, for example, in IBDs. ${ }^{24}$ As corroborated by several clinical and animal studies, ${ }^{25-28}$ IBD is associated with a drastic decrease in intestinal barrier integrity, which can often be by a systemic immune activation. ${ }^{24,29}$ In the present study, the decreased $\mathrm{P}_{\text {app }}$ and stable TER after acute (24 hours) treatment of the coculture model with LPS $(1 \mu \mathrm{g} / \mathrm{mL})$ and $3 \mathrm{C}$ might be an indication of a strengthened barrier in order to prevent a subepithelial translocation of harmful pathogens and inert matter. Thus, the strengthened epithelial barrier prevents a potential inflammatory overreaction by the underlying endothelial cells. A recent study reported a reduction in Caco-2 TER and an increase of paracellular flux after $0.3 \mu \mathrm{g} / \mathrm{mL}$ LPS treatment over a 5-day period. ${ }^{29}$ Another study described a stable Caco-2 barrier after $50 \mu \mathrm{g} / \mathrm{mL}$ LPS treatment for 24 hours $^{30}$ as was also observed in our study, in which a stable TER was maintained over a 24-hour incubation period after incubation with $1 \mu \mathrm{g} / \mathrm{mL}$ LPS. These findings indicate that the incubation time might be a crucial factor in the outcome of barrier integrity after LPS challenge.

The barrier function data from both methods shown in Figure 6 are of major significance, as both TER and apparent permeability coefficient are generally taken as valid experimental parameters of barrier integrity. However, although all four stimuli did not modify TER levels, the cytokine cocktail and the $\mathrm{Ba} / \mathrm{Gd}$ nanoparticles, as well as their combination, elicited a statistically significant reduction in transport of the fluorescent tracer molecule. We conclude from this that, as the latter technique appears more sensitive than TER measurements, both techniques should be employed when studying barrier function. Had only TER been taken as a measure of barrier function, the observation of a strengthened mucosal barrier would have been missed.

Interestingly, after apical LPS stimulation, the ISO-HAS-1 monoculture responded with a rapid increase in IL-8 release into the apical compartment. This represents a release of IL- 8 on their basolateral side (in situ into the lamina propria). After apical INF- $\gamma$ application, ISO-HAS-1 released IL-8 to the apical side, representing an inflammatory signal, which is forwarded into the systemic circulation. These in vitro observations indicate a confluent, functional endothelial monolayer exhibiting appropriate cellular differentiation and polarity. This basolateral IL-8 response could not be detected for ISO-HAS-1 in coculture with Caco-2 indicating a protective influence of the Caco-2 provided by an increase in the barrier properties, which could be demonstrated by a decreased $\mathrm{P}_{\text {app }}$. The particle
$\mathrm{Ba} / \mathrm{Gd}$ did not cause a change in the IL-8 response in the coculture or in the ISO-HAS-1 monoculture. No change was observed in the unstimulated culture, and no altered IL-8 response on the cultures stimulated with $3 \mathrm{C}(\mathrm{Ba} / \mathrm{Gd}+3 \mathrm{C})$. The Caco- 2 monocultures demonstrated an altered reaction in the basolateral compartment following $\mathrm{Ba} / \mathrm{Gd}$ treatment. After apical application of the particle or 3C, the IL-8 level decreased significantly in the basolateral well compared to the uc, whereas in Caco- 2 costimulated with the nanoparticle and $3 \mathrm{C}$, a clear increase of IL-8 occurred in the basolateral compartment compared to the uc. The basolateral decrease of IL-8 may be due to the reinforced barrier integrity, thus the diffusion of apically released IL- 8 to the basolateral compartment may have been restricted and decelerated. A further plausible explanation could also be an altered pro- and anti-inflammatory cytokine homeostasis of the Caco-2 cells. Primary pathogen recognition is initiated by intestinal epithelial cells. They are known to produce a large variety of immune-regulatory signals to balance gut mucosal immunity, which prevent an inflammatory overreaction of subepithelial immune cells. ${ }^{24}$

This basolateral IL- 8 decrease, which was seen in the Caco-2 monoculture upon apical $\mathrm{Ba} / \mathrm{Gd}$ and $3 \mathrm{C}$ treatments, was not observed in the coculture. Basolaterally detected IL-8 levels remained unaltered compared to the uc. However, the baseline basolateral level of IL- 8 for the ISO-HAS-1 was higher compared to the Caco-2 monoculture. Hence, the baseline IL-8 level may be responsible for the cytokine response seen in the Caco- 2 monoculture. In the Caco- 2 monoculture, LPS, TNF- $\alpha$, and INF- $\gamma$ did not result in a release of sICAM-1, whereas IL1- $\beta$ caused a distinct apical sICAM-1 release. Although the mixture of all cytokines $3 \mathrm{C}$ did not provoke elevated sICAM-1 levels, Ba/Gd application did lead to a significant apical and basolateral sICAM-1 production. The combination of $\mathrm{Ba} / \mathrm{Gd}$ and $3 \mathrm{C}$ provoked an even higher apical and basolateral sICAM-1 release compared to Ba/Gd alone. Thus $\mathrm{Ba} / \mathrm{Gd}$ exacerbated the inflammatory response caused by the addition of the pooled inflammatory cytokines in the in vitro barrier model. It has been previously shown that the onset of chronic IBD is accompanied by the surface expression of cellular adhesion molecules such as ICAM-1 as well as E-selectin, as was observed in the barrier model presented in this study. ${ }^{31-33}$ According to the findings obtained for the Caco-2 monoculture, it may be assumed that $\mathrm{Ba} / \mathrm{Gd}$ in its current developmental state may trigger sICAM-1 release in vivo. These results, together with the elevated IL-8 release indicate that $\mathrm{Ba} / \mathrm{Gd}$ may exacerbate already present inflammation as well as the formation of crypt abscesses in IBD. 
In the coculture, however, $\mathrm{Ba} / \mathrm{Gd}$ did not cause an IL-8 or sICAM-1 response and did not exacerbate the inflammatory response of the barrier after combined exposure with the pooled inflammatory cytokines. Thus, the inflammatory responsiveness of the coculture appears less vigorous compared to the Caco-2 as well as ISO-HAS-1 monoculture. Nevertheless, it should be mentioned that the apical baseline level of released SICAM-1 in the coculture is higher compared to the Caco-2 monoculture, indicating a mutual impact on the two cell types, which might also be an artifact of the two tumor cell lines. To verify this assumption, these studies need to be repeated with the respective primary cells. As has already been shown in previous studies, the lower resorbability of $\mathrm{BaSO}_{4}$ may lead to a general foreign body reaction in the body external to the intestinal tract and in rare cases it can result in granuloma formation. ${ }^{34,35}$ This needs to be taken into consideration when applying novel nanoparticles, especially when the intestinal barrier is already breached, which is often the case in chronic IBD. In other regions of the body, such as the lung, a slight neutrophil increase in bronchoalveolar lavage of mice after inhalation of $\mathrm{BaSO}_{4}$ nanoparticles was reported. ${ }^{36}$

Furthermore, the epithelial layer in the intestine is the first cell type that encounters the particle coating DTPMPA and the toxic effect of the coating needs to be evaluated. DTPMPA is approved by the US Food and Drug Administration, is considered to be nontoxic and is a powerful sequestrant for metal ions such as $\mathrm{BaSO}_{4}$. Since the $\mathrm{Ba} / \mathrm{Gd}$ particle is stable in $\mathrm{pH}$-neutral media and no $\mathrm{Gd}$ ion release occurs, which could also cause cytotoxic effects, most likely only negligible inflammatory responses will be caused by $\mathrm{Gd}$ ions. The ISO-HAS-1 monoculture responded to $3 \mathrm{C}$ with an apical and basolateral sICAM-1 production, whereas $\mathrm{Ba} / \mathrm{Gd}$ did not show any effects and no exacerbation of inflammatory responses was detected in the cells. In addition, the apical application of TNF- $\alpha$ (exposure of TNF- $\alpha$ to the ISO-HAS-1 basolateral cell membrane) caused a basolateral sICAM-1 release (sICAM-1 release from the ISO-HAS-1 apical cell membrane), which would represent sICAM-1 release into the systemic circulation in vivo. As resumed by Blann et al, ${ }^{37}$ current studies suggest a contribution of ICAM to pathophysiological progression in cardiovascular, connective tissue, or neoplastic diseases. Soluble cell adhesion molecules such as sICAM-1 as well as sE-selectin are considered as important key biomarkers for inflammatory processes. The ISO-HAS-1 responded to all proinflammatory stimuli, except IL1- $\beta$, with a sE-selectin release in both (upper and lower) compartments. Incubation with $\mathrm{Ba} / \mathrm{Gd}$ did not result in any sE-selectin release, although a release was detected in the lower compartment when $\mathrm{Ba} / \mathrm{Gd}$ was combined with the cytokine mixture $3 \mathrm{C}$, as well as in both compartments for $3 \mathrm{C}$ alone.

Just as described above for sICAM-1, sE-selectin has been identified as a biomarker for the diagnosis of chronic IBD and the level is an indicator of the severity of the disease. Several studies have already postulated increased sE-selectin plasma levels in active $\mathrm{UC}$ and $\mathrm{CD}$, but not in inactive $\mathrm{UC}$ and $\mathrm{CD}$ in which sE-selectin levels predominate as is observed in healthy patients. ${ }^{33,38,39}$ The coculture exhibited similar results to the Caco-2 monoculture and no sE-selectin was detected in the supernatants. Thus, the epithelial cells formed a substantial barrier, even under inflammatory conditions, that prevent $\mathrm{sE}$-selectin inducing factors from diffusing to the endothelial cells. However, since a basolateral sICAM-1 release was detected in the coculture during exposure with $3 \mathrm{C}$, this mimics the in vivo situation in which sICAM-1 is released into the systemic circulation, whereas E-selectin may remain bound to the membrane. Further studies with enzyme immunoassays are needed to verify if E-selectin and ICAM-1 are membrane-bound in the transwell. In the Caco-2 monoculture, an sICAM-1 release into both the upper and lower compartment was detected, in addition to a decreased IL-8 release. Although this does not appear to be an "inflammatory" reaction, it may serve as an attraction mechanism for anti- or non-inflammatory phagocytes. These cells are responsible for eliminating particulate matter and prevent an over-induction of the inflammatory response in vivo.

In summary, the multicell in vitro model of the intestinal barrier is shown to exhibit many in vivo-like features and could thus be suitable for examining inflammatory responses after exposure to diverse external stimuli. Therefore, this model may serve as a promising tool and an alternative to animal studies.

\section{Disclosure}

The authors report no conflicts of interest in this work.

\section{References}

1. Heidemann J, Domschke W, Kucharzik T, Maaser C. Intestinal microvascular endothelium and innate immunity in inflammatory bowel disease: a second line of defense? Infect Immun. 2006;74(10): 5425-5432.

2. Binion DG, West GA, Ina K, Ziats NP, Emancipator SN, Fiocchi C. Enhanced leukocyte binding by intestinal microvascular endothelial cells in inflammatory bowel disease. Gastroenterology. 1997;112(6): 1895-1907.

3. Ogawa H, Rafiee P, Heidemann J, et al. Mechanisms of endotoxin tolerance in human intestinal microvascular endothelial cells. J Immunol. 2003; 170(12):5956-5964. 
4. Masuzawa M, Fujimura T, Hamada Y, et al. Establishment of a human hemangiosarcoma cell line (ISO-HAS). Int $J$ Cancer. 1999;81(2): 305-308.

5. Unger RE, Krump-Konvalinkova V, Peters K, Kirkpatrick CJ. In vitro expression of the endothelial phenotype: comparative study of primary isolated cells and cell lines, including the novel cell line HPMECST1.6R. Microvasc Res. 2002;64(3):384-397.

6. Pinto M, Robineleon S, Appay MD, et al. Enterocyte-like differentiation and polarization of the human-colon carcinoma cell-line caco-2 in culture. Biol Cell. 1983;47(3):323-330.

7. Sambuy Y, De Angelis I, Ranaldi G, Scarino ML, Stammati A, Zucco F. The Caco-2 cell line as a model of the intestinal barrier: influence of cell and culture-related factors on Caco-2 cell functional characteristics. Cell Biol Toxicol. 2005;21(1):1-26.

8. Hidalgo IJ, Raub TJ, Borchardt RT. Characterization of the human colon carcinoma cell line (Caco-2) as a model system for intestinal epithelial permeability. Gastroenterology. 1989;96(3):736-749.

9. Hermanns MI, Kasper J, Dubruel P, et al. An impaired alveolarcapillary barrier in vitro: effect of proinflammatory cytokines and consequences on nanocarrier interaction. $J R$ Soc Interface. 2010;7 Suppl 1:S41-S54.

10. Kasper J, Hermanns MI, Bantz C, et al. Inflammatory and cytotoxic responses of an alveolar-capillary coculture model to silica nanoparticles: comparison with conventional monocultures. Part Fibre Toxicol. 2011; $8(1): 6$.

11. Kasper J, Hermanns MI, Bantz C, et al. Flotillin-involved uptake of silica nanoparticles and responses of an alveolar-capillary barrier in vitro. Eur J Pharm Biopharm. 2013;84(2):275-287.

12. Papritz M, Pohl C, Wubbeke C, et al. Side-specific effects by cadmium exposure: apical and basolateral treatment in a coculture model of the blood-air barrier. Toxicol Appl Pharmacol. 2010;245(3):361-369.

13. Pohl C, Papritz M, Moisch M, et al. Acute morphological and toxicological effects in a human bronchial coculture model after sulphur mustard exposure. Toxicol Sci. 2009;112:482-489.

14. Perazella MA. Current status of gadolinium toxicity in patients with kidney disease. Clin J Am Soc Nephrol. 2009;4(2):461-469.

15. Do C, Barnes JL, Tan C, Wagner B. Type of MRI contrast, tissue gadolinium, and fibrosis. Am J Physiol Renal Physiol. 2014;307:F844-F855.

16. Perazella MA. Advanced kidney disease, gadolinium and nephrogenic systemic fibrosis: the perfect storm. Curr Opin Nephrol Hypertens. 2009;18(6):519-525.

17. Agarwal R, Brunelli SM, Williams K, Mitchell MD, Feldman HI, Umscheid CA. Gadolinium-based contrast agents and nephrogenic systemic fibrosis: a systematic review and meta-analysis. Nephrol Dial Transplant. 2009;24(3):856-863.

18. Kraegeloh A, NanoKon-Konsortium. NanoKon-Systematische Bewertung der Gesundheitsauswirkungen nanoskaliger Kontrastmittel. Saarbrücken: INM - Leibniz-Institut für Neue Materialien gGmbH; Berichtszeitraum: October 01, 2010-December 31, 2013, published in 2014. German.

19. Pereira C, Araujo F, Barrias CC, Granja PL, Sarmento B. Dissecting stromal-epithelial interactions in a $3 \mathrm{D}$ in vitro cellularized intestinal model for permeability studies. Biomaterials. 2015;56:36-45.

20. Matsusaki M, Hikimoto D, Nishiguchi A, et al. 3D-fibroblast tissues constructed by a cell-coat technology enhance tight-junction formation of human colon epithelial cells. Biochem Biophys Res Commun. 2015; 457(3):363-369.

International Journal of Nanomedicine

\section{Publish your work in this journal}

The International Journal of Nanomedicine is an international, peerreviewed journal focusing on the application of nanotechnology in diagnostics, therapeutics, and drug delivery systems throughout the biomedical field. This journal is indexed on PubMed Central, MedLine, CAS, SciSearch ${ }^{\circledR}$, Current Contents ${ }^{\circledR} /$ Clinical Medicine,
21. Leonard F, Collnot EM, Lehr CM. A three-dimensional coculture of enterocytes, monocytes and dendritic cells to model inflamed intestinal mucosa in vitro. Mol Pharm. 2010;7(6):2103-2119.

22. Susewind J, de Souza Carvalho-Wodarz C, Repnik U, et al. A 3D coculture of three human cell lines to model the inflamed intestinal mucosa for safety testing of nanomaterials. Nanotoxicology. 2015:1-10.

23. Mahler S. Mast cell tumour in a young boxer dog. Vet Rec. 2012; 171(7): 182 .

24. Peterson LW, Artis D. Intestinal epithelial cells: regulators of barrier function and immune homeostasis. Nat Rev Immunol. 2014;14(3): 141-153.

25. Turner JR. Intestinal mucosal barrier function in health and disease. Nat Rev Immunol. 2009;9(11):799-809.

26. Arrieta MC, Madsen K, Doyle J, Meddings J. Reducing small intestinal permeability attenuates colitis in the IL10 gene-deficient mouse. Gut. 2009; 58(1):41-48.

27. Berman L, Moss RL. Necrotizing enterocolitis: an update. Semin Fetal Neonatal Med. 2011;16(3):145-150.

28. Clark JA, Doelle SM, Halpern MD, et al. Intestinal barrier failure during experimental necrotizing enterocolitis: protective effect of EGF treatment. Am J Physiol Gastrointest Liver Physiol. 2006;291(5): G938-G949.

29. Guo S, Al-Sadi R, Said HM, Ma TY. Lipopolysaccharide causes an increase in intestinal tight junction permeability in vitro and in vivo by inducing enterocyte membrane expression and localization of TLR-4 and CD14. Am J Pathol. 2013;182(2):375-387.

30. Yu LC, Huang CY, Kuo WT, Sayer H, Turner JR, Buret AG. SGLT1 -mediated glucose uptake protects human intestinal epithelial cells against Giardia duodenalis-induced apoptosis. Int J Parasitol. 2008;38(8-9):923-934.

31. Nieder JB, Hussels M, Bittl R, Brecht M. Effect of TMAO and betaine on the energy landscape of photosystem I. Biochim Biophys Acta. 2014;1837(6):849-856.

32. Hussell T, Bell TJ. Alveolar macrophages: plasticity in a tissue-specific context. Nat Rev Immunol. 2014;14(2):81-93.

33. Bhatti M, Chapman P, Peters M, Haskard D, Hodgson HJ. Visualising E-selectin in the detection and evaluation of inflammatory bowel disease. Gut. 1998;43(1):40-47.

34. Lewis JW Jr, Kerstein MD, Koss N. Barium granuloma of the rectum: an uncommon complication of barium enema. Ann Surg. 1975;181(4): 418-423.

35. Mayorga M, Castro F, Fernandez F, Val-Bernal F, Arribas V. Radiohistology and histochemistry of barium granuloma of the colon and rectum. Histol Histopathol. 1992;7(4):625-628.

36. Mahler A, Steiniger J, Bock M, et al. Is metabolic flexibility altered in multiple sclerosis patients? PLoS One. 2012;7(8):e43675.

37. Blann AD, Ridker PM, Lip GY. Inflammation, cell adhesion molecules, and stroke: tools in pathophysiology and epidemiology? Stroke. 2002; 33(9):2141-2143.

38. Patel RT, Pall AA, Adu D, Keighley MR. Circulating soluble adhesion molecules in inflammatory bowel disease. Eur J Gastroenterol Hepatol. 1995; 7(11):1037-1041.

39. Nielsen OH, Brynskov J, Vainer B. Increased mucosal concentrations of soluble intercellular adhesion molecule-1 (sICAM-1), sE-selectin, and interleukin-8 in active ulcerative colitis. Dig Dis Sci. 1996; 41(9):1780-1785.

Journal Citation Reports/Science Edition, EMBase, Scopus and the Elsevier Bibliographic databases. The manuscript management system is completely online and includes a very quick and fair peer-review system, which is all easy to use. Visit http://www.dovepress.com/ testimonials.php to read real quotes from published authors. 